\title{
ENVIRONMENTAL CONCEPTIONS AND THE IDEOLOGICAL COMMITMENTS THAT GUIDE THE MANAGEMENT OF THE ENVIRONMENTAL ORGANIZATIONS
}

Submission: 22/06/2017 Accept: 03/03/2018

José Kennedy Lopes Silva ${ }^{1}$ Osmar Siena²

\begin{abstract}
Environmental organizations actively take part in the proposition of strategies, studies and environmental practices that aim at reducing the environmental degradation of the planet. These organizations have conceptions and commitments that guide their actions. The objective of the research that led to this article was to understand the environmental conceptions and the ideological commitments that guide the actions and the management of the environmental organizations. The research focused on three environmental organizations, two located in the state of Mato Grosso and one in the state of Rondônia, all of them belonging to the Brazilian Legal Amazon region. A qualitative research with multiple case study was carried out. Participant observation, semi-structured interviews and documentary analysis were used as strategies. Several environmental conceptions that influence the performance and management of organizations were identified, with a greater presence of the socio-environmentalist and of the environmental justice conceptions. However, the latter is not discussed strategically. Regarding the ideological commitments, the eco-socialist vision is the one that seems to have more influence over organizations.
\end{abstract}

Keywords: Environmental Organizations. Environmental Movement. Environmental Conceptions. 


\section{RESUMO}

As organizações ambientalistas participam ativamente na construção de estratégias, estudos $e$ práticas ambientais que visam diminuir a degradação ambiental no planeta. Essas organizações assumem concepções e compromissos que orientam sua atuação. $O$ objetivo da pesquisa que deu origem a este artigo foi o de compreender as concepções ambientais e os compromissos ideológicos que norteiam a atuação e a gestão das organizações ambientalistas. O locus da pesquisa são três organizações ambientalistas, duas situadas no estado do Mato Grosso e uma no estado de Rondônia, pertencentes à Amazônia Legal brasileira. Realizou-se pesquisa qualitativa com estudo de casos múltiplos. Como estratégias, foram utilizadas a observação-participante, a entrevista semiestruturada e a análise documental. Identificaram-se diversas concepções ambientais que influenciam a atuação e a gestão das organizações, com maior presença das concepções socioambientalista e justiça ambiental. No entanto, a última não é discutida estratégicamente pelas organizações. Em relação aos compromissos ideológicos, a visão ecossocialista é a que parece exercer mais influência nas organizações.

Palavras-chave: Organizações Ambientalistas. Movimento Ambientalista. Concepções Ambientais.

\section{INTRODUCTION}

Arising on the wake of and with the support of the guiding principles of the social movements and of the environmental movement, environmental organizations are important for the development of policies aimed at the sustainable development. These organizations were institutionalized and contribute to the valorization of the environmental agenda regarding the practices and public policies of private organizations and the public sector (LOSEKANN, 2014; CASTELLS, 1999). They actively take part in proposing strategies, studies and environmental practices that contribute to reducing the environmental degradation of the planet. In their formation, environmental organizations adopt various visions of the environment, which differentiate one from another according to their goals and their actions. These views or environmental conceptions can be seen as a sociological stand on the various interrelations that modify and/or adjust the proposals and practices, aiming at the protection of nature and of its sustainability. According to this perspective, environmental conceptions are the guidance, the vision or the way of thought of social agents, public agencies, organizations and of other segments, regarding the various stands on the practices and on environmental discussions that arise from the approaches to the relationship established between humans and nature (MENEZES, 2008). Environmental conceptions influence organizations in identifying problems and finding solutions to achieve objectives.

According to Martinez-Alier (2007), there are three main environmental conceptions: "cult of wilderness", "the gospel of eco-efficiency" and "environmentalism of the poor". Diegues (1998) classifies the environmental conceptions in "preservationist", "conservationist", "sustainabilist" and "socio-environmentalist". Leff $(2002$; 2004; 2006; 2008) presents his vision of the environmental conceptions as being the "environmental knowledge" and the "environmental rationality", based on three theoretical backgrounds - Marxist, Foucauldian and Weberian. According to Viola $(1987 ; 1992)$, the conceptions can be related to four ideological commitments: fundamentalist environmentalism, realistic environmentalism, eco-socialism and eco-capitalism.

Environmental conceptions influence the organizations on diagnosing problems and finding solutions in order to meet objectives. It is possible that the environmental conceptions, that guide the management and the performance of environmental organizations, are strongly influenced by the different branches of the environmental movement.

Considering the evidence of a strong link between environmental movements and the role played by environmental organizations, it is possible that the environmental conceptions, which guide the management and performance of the environmental organizations, can be 
strongly influenced by the different aspects of the environmental movement. For that reason, understanding what conception or conceptions guide the performance and the activities of the environmental organizations can contribute to analyzing and evaluating them. Nevertheless, the Brazilian literature on these issues is scarce, only being abundant the literature on the importance and on the role of non-governmental organizations (NGOs) and on the environmental currents of social movements and groups (SILVA; SIENA, 2014). The identification of this gap motivated this research. Considering the importance of the identification and of the influence of the environmental conceptions, an answer to the following question was attempted: what are environmental conceptions and ideological commitments that conduct the management and the performance of the environmental organizations? Guided by this question, this study intended to understand what environmental conceptions influence the management and the performance of these organizations.

The empirical basis to address the question referred previously focused on three organizations located in the Brazilian Legal Amazon region, which, according to Becker (2005), is a territory destined for the preservation and conservation of nature, what enabled the initiation of the environmental movement in the region. They deserve to be recognized as environmental organizations that work in projects and public policies related to the biodiversity of the Amazonian areas (LOUREIRO; PACHECO, 1995). There are notable environmental organizations working in projects and public policies related to the biodiversity in Amazonian areas. Similarly to Becker (2005), Zhouri (2006) emphasizes that the work of the environmental organizations in the Legal Amazon is complex, once, in that region, there are many tensions involving economic, social and environmental aspects, which makes the environmental organizations base their work on the concepts of "sustainable development" and "achievement of sustainability".

Therefore, these organizations are essential for the practice of sustainable development policies. They participate actively in the construction of environmental strategies, studies and practices. Their objective is always to reduce the environmental degradation of the planet and to allow the existence and permanence of such organizations (SILVA; SIENA, 2016). Researches with the proposed epistemological bias carried out in the Administration field, mainly in the relation to investigations directed to the Organizational Studies, are necessary in order to understand the environmental conceptions and the ideological commitments that guide the execution of the activities here mentioned. These aspects impact the objectives, the management and the relationship with the stakeholders of such organizations. It is important, therefore, to discuss the their activities based on their conceptions and their philosophies practiced in the management and performance, so that it can be understood how they work, given the importance of these organizations in regions such as the Legal Amazon.

In this article, two organizations from the state of Mato Grosso (MT) and one from the state of Rondônia (RO) are investigated. In Mato Grosso, are located the Federação de Órgãos para Assistência Social e Educacional (FASE-MT), from the city of Cáceres, and the Instituto Ouro Verde (IOV), based in the city of Alta Floresta. The work of the first organization consists in contributing to the creation of alternatives to the current model of development, through the dissemination of the agroecology, of voluntary associations, of the articulation among political agents and of the communication in community radios and audiovisual projects. The second organization works with farmers in the northern region of the state of Mato Grosso, promoting the social participation aiming at the sustainable development. In Rondônia, the Association Kanindé (KANINDÉ) for Ethno-environmental Defense, established in Porto Velho is engaged on the defense of the environment and works with indigenous and riverine peoples, promoting sustainable management plans for extractive reserves and protected areas in the state of Rondônia, in the 
northwest region of the state of Mato Grosso and in the southern region of the state of Amazonas. The following hypothesis was suggested: in environmental organizations, the most common environmental conceptions are the sustainabilist, the socio-environmentalist and the conservationist and the most common ideological commitment is the eco-socialist.

\section{THEORETICAL FRAMEWORK}

This section is dedicated to the environmental and social movements, as well as to the ideological commitments, theories of theoretical bases and environmental conceptions.

\subsection{Environmentalist and Environmental Movement}

The objective of the environmentalism lies beyond an environmental identity and a social group and implies the proposition of a new project of society. In this project, the environmentalism is the agent capable of establishing a dialogue among the different classes, from the most aligned with the environmental issues to the predatory and short sighted society. "Environmentalism" refers to the "practices and discourses developed in a collective way aiming at correcting or improving the relationships of mankind with nature (MARTíNEZ-ALIER, 2002; CASTELLS, 1999). The environmental practices historically arise in the United Kingdom, in Germany, in Italy and in other countries in Europe and in the United States, in a period when the habits related to nature, namely to the forests, started to change due to the awareness of the existence of natural areas already significantly harmed or nearly extinct. The most combative form of environmentalism, on its turn, arouse in the Caribbean, in India and in South Africa, which contradicts the common idea that he environmentalism only emerged in developed countries. In Brazil, environmentalism was not imported, because the discussions about the environmental, whose first registers date back to 1820-1920, helped to build the country, mainly through the opposition to the exploitation during the colonial period (PÁDUA, 1997; SCHWARTZMAN, 2000). In table 1, an overview of the historical development of the environmental movement is presented for a better understanding of the formation of the environmentalism and its interaction with the social and environmental groups in several countries.

The work shown in the construction of the environmentalism, in the discussions of Pepper (1996) and Goldsmith (1995), which deal with modern environmentalism and the environmental obstacles in relation to the perspectives based on the defense of nature, through the construction of dialogues in harmony with society, seek a counterpoint in relation to the capitalist values and activities that historically differ from actions aimed the protection of the environment.

Table 1 - Summary of the characteristics of the environmental movement.

\begin{tabular}{|c|l|}
\hline Characteristics & \multicolumn{1}{c|}{ Chronology } \\
\hline $\begin{array}{c}\text { Environmentalist } \\
\text { thought }\end{array}$ & $\begin{array}{l}16^{\text {th }} \text { century: Emergence of agriculture and changes in the way of life of the popula- } \\
\text { tion's life styles. }\end{array}$ \\
\hline $\begin{array}{c}\text { Socialism and en- } \\
\text { vironmentalism }\end{array}$ & $\begin{array}{l}\text { Opposition to the changes brought by the Industrial Revolution in the } 17^{\text {th }} \text { and } 18^{\text {th }} \\
\text { centuries. }\end{array}$ \\
\hline $\begin{array}{c}\text { Environmental } \\
\text { groups and econo- } \\
\text { mic growth }\end{array}$ & $\begin{array}{l}19^{\text {th }} \text { century: Environmental groups, formed by landowners, were influenced by the roman- } \\
\text { tic environmental thought. Due to the Industrial Revolution, which led to economic growth, } \\
\text { and to the two world wars, environmentalism grew in Europe and in North America. }\end{array}$ \\
\hline $\begin{array}{c}\text { Environmental le- } \\
\text { gislation in Brazil }\end{array}$ & $\begin{array}{l}1920-1970 \text { - Brazilian environmentalism is developed in the urban context and, } \\
\text { through legal measures, there is an increase of the environmental awareness. }\end{array}$ \\
\hline
\end{tabular}




\begin{tabular}{|c|l|}
\hline $\begin{array}{c}\text { Emergence of the } \\
\text { environmental } \\
\text { agenda }\end{array}$ & $\begin{array}{l}\text { The book "Silent spring", the global think tank Club of Rome, the United Nations Ge- } \\
\text { neral Assembly and the United Nations Conference on the Human Environment (1972) } \\
\text { spread the environmental agenda worldwide, leading to the origin and systematization } \\
\text { of many environmental organizations, as well as of the "new environmentalism". }\end{array}$ \\
\hline $\begin{array}{c}\text { Ecologism in social } \\
\text { movements }\end{array}$ & $\begin{array}{l}\text { In Brazil, in the 1980s, there is the strengthening of the trade unions and of the social } \\
\text { movement through "green" political parties and social organizations, which resulted } \\
\text { in a combative and denouncing environmentalism. }\end{array}$ \\
\hline $\begin{array}{c}\text { Political conso- } \\
\text { lidation of the } \\
\text { environmental } \\
\text { movement }\end{array}$ & $\begin{array}{l}\text { In the 1990s, the environmental movement got closer to the communities through major } \\
\text { events that took place and through globalization. The environmental movement and the } \\
\text { environmental discussion became strategic in the public agenda of the countries; in Bra- } \\
\text { zil, the environmental movement becomes plural and present in many sectors. }\end{array}$ \\
\hline $\begin{array}{c}\text { Social movement } \\
\text { ments }\end{array}$ & $\begin{array}{l}\text { From the 1990s and 2000s onwards, environmentalism changes into social move- } \\
\text { ments with the creation of forums of the non-governmental organizations that guide } \\
\text { the debates about public policies for the environment. }\end{array}$ \\
\hline
\end{tabular}

Source: Adapted from Ruckert (2015); Leroy (2013); Gohn (2011); Dias (2009); Montibeller-Filho (2006); Zhouri, (2006); Diegues (1998;2000); Drummond (1997); Pádua (1997); Viola; Vieira (1992).

The transformations and social changes define the process of globalization and, consequently, affect the ecological issues. Therefore, politics and the political theory have to consider the environmental reactions. In this sense, Viola, from the 1990s onwards, claims that the "environmentalism" is multisectoral. This does not mean that the concepts of the commitments can be seen as outdated or unnecessary; what occurred was that the environmental studies adapted themselves to a broader context (BOEIRA, 2015; LEIS, 2004). The various environmental movements, with many different features and goals, gave rise to various environmental conceptions, being, simultaneously, a result of them.

\subsection{Environmental conceptions}

The conception "cult of wilderness" intends to promote the preservation of the fauna and flora reserves, but is not opposed to the economic growth, proposing instead a containment of the consumption of natural resources. Moreover, it defends nature and the sacred worship of animals and it cultivates a harmonious stand towards the different religions, especially the less anthropocentric ones (MARTINEZ-ALIER, 2007).

The preservationist conception is the environmental design that seeks to address the "wildlife". People and institutions that follow the preservationism are totally opposed to the use of natural resources. The main objective of this conception is the maintenance of the biodiversity, regardless of the human needs of the use of natural resources (DIEGUES, 1998; 2000; PIMBERT; PRETTY, 2000).

The conservationist conception advocates the preservation of the natural resources for the future generations, that is, the activists of this current seek a harmonious relationship between human beings and nature, aiming at the sustainable development and, thus, at improving the quality of life of the population (DIEGUES, 1998). Conservationists believe that the natural areas are useful for the society and can be used as laboratories by researchers and as resources and therefore must be protected from human actions (GÓMEZ-POMPA; KAUS, 2000).

The sustainabilist conception has as its primary concern the attention to technology that may trigger the economic growth, in order to reduce the problems caused by industrialization, agriculture and urban growth. The sustainabilism seeks an alignment between technology and the environment in order to achieve sustainability (MENEZES; SIENA, 2010). The eco-efficiency, a conception discussed by Martínez-Alier (2007), advocates economic growth, but not at any cost. This premise fits the eco-efficiency conception into a sustainabilist approach. For this reason, in this work, this current is dealt with as part of the sustainabilist conception. 
The socio-environmentalist conception inherited the principles of the ecologism and is based on the creation of protected natural parks, as well as on the proposal of social movements aiming at the respect for the cultural diversity for the maintenance of the biological diversity through a harmonious relationship between man and nature, with a democratic management of the natural territories (DIEGUES, 1998). This conception is a reflection of the changes that occurred in Brazil during the 1980s: the replacement of a military regime for a civilian rule, the emergence and strengthening of the NGOs, the expansion of the debate on the environmental issues, with the formation of new forums in the country and in the world, and a greater nearness of environmentalists to the political field through the articulations and the policies of the social and environmental movements (JACOBI, 2003; SANTILLI, 2005; VIOLA; VIEIRA, 1992). The Compensation for Environmental Services (CES) is presented as a practical example of the application of the socio-environmentalist model. The model consists of strategies that stimulate the conservation and reparation of the environment through awards and financial compensations that aim at solidifying actions in the social, economic and environmental fields of rural, riverine and indigenous communities, among others (BORN, 2002).

Socio-environmentalism emerges as an alternative that allows to reconcile the environmental preservation and the human presence in areas of protection and also intends to reconcile the environmentalists and social movements. The interaction among these agents results in a strengthening of the importance of the issues related to nature and promotes greater participation of the population in the debate on natural and social resources, especially in the peripheral and more degraded regions of the country, such as those in the North and Northeast of Brazil and in the Legal Amazon.

The so-called environmentalism of the poor or environmental justice is based on a social concern with the minorities and traditional communities, such as indigenous, extractive and peasant farmers, and with biodiversity and environmental racism of the environmental injustices. In all countries, there are examples of actions of environmental organizations based on the propositions of social and environmental justice (MARTínEZ-ALIER, 2002; 2007).

\subsection{Ideological commitments}

Environmentalists that support the preservationist and the "cult of wilderness" conceptions share the eco-fundamentalist ideological commitment, once they have a more radical and anarchic vision of the natural world than other commitments. These activists believe in the possibility of building an ecological society emerged in the more peripheral regions of the country and are quite pessimistic, basing their activities on an ecological radicalism and on the belief that society will destroy the planet. Having difficulties in dialoguing with society, public authorities and entrepreneurs, this ecological position has little support outside the environmental movement (VIOLA, 1987a).

The eco-realistic ideological commitment is similar to the eco-efficiency conception. The adepts of this current believe that society can be transformed through an environmental movement that is rigid in its structure and flexible in the interaction with society and with a socio-economic system based on small private properties, differently from the capitalist and socialist systems (VIOLA, 1987a). The realistic ecologists support changes in society reached through discussions about the environment and believe in the cooperativism, a productive system controlled by self-management.

The eco-socialist ideological commitment is associated with the socio-environmentalist and with the environmentalism of the poor (or environmental justice) conceptions. This commitment is the most radical one regarding the discussion of the economic systems, once its supporters are in favor of the abolition of the capitalist system, claiming that it harms the environment. The orientation of this commitment is Marxist, a theory that, although unorthodox, is 
essential for the constitution of the basis of this conception (MEBRATU, 1998; VIOLA, 1987b). The eco-socialists are more active in the construction of the environmental movement than realistic environmentalists. Their political militancy enables them to engage more people in participating in the discussions of the environmental problems and they concentrate efforts in mobilizing workers and the popular sectors, such as the traditional rural communities (VIOLA, 1987a). The eco-socialists base their assumptions on two arguments: the first is that the capitalist model of production and consumption destroys the environment and causes all the current ecological crises; the second states that the capitalist strategies result in a totally unequal "progress", which contradicts the ecological reasoning of the economic and natural resources division (LOWY, 2014).

The eco-capitalist commitment sees the market as an allocator of resources and supports the social welfare in the prejudice of the ecological. Activists of this conception advocate an optimistic view towards other ecological positions for the future. In the global social ecologist movement, the eco-capitalist conception is the one that stands out the most, especially in the sectors in favor of the Western ideas, accompanied, in second place, by the realist ecologists (VIOLA, 1987b). Regarding the differences between the eco-socialists and eco-capitalists, Boff (1995) states that these differences exist because the first conception is based on the socialist system and the second, on the capitalist system.

\subsection{Theories}

Leff $(2002 ; 2004 ; 2006 ; 2008)$ proposes that the environmental conceptions be approached through an understanding of the environmental rationality and of the "environmental knowledge", which can be understood through the study of three theories - Weber's concept of "rationality", Foucault's concept of "environmental knowledge" and Marx's socioeconomic analysis. The epistemological tensions involving a view of the three authors studied by Leff are evident. Therefore, in this study, the theories are studied as conceptual orientations for the practices of governance, for the strategies used by the environmental organizations, for the management of the natural resources and for the efficiency of the objectives related to sustainability. According to Ruckert (2015), Leff identifies the need to enhance the Environmental rationality and the Environmental Awareness in environmental practices related to the changes in society regarding nature, culture, consumption habits and technology.

Weber's environmental rationality is articulated through the interaction of four levels of rationality: a) the substantive rationality implies a system to guide the social processes for the formation of the environmental rationality, based on the foundations of the sustainable development and of the cultural and political pluralism; b) the theoretical rationality allows the discussion and the conscious control of reality through concepts and values from the substantive rationality in order to support the productive rationality, based on an environmental policy for the development; c) instrumental rationality is the Weberian level of rationality that results in the production of effective techniques with functional links that regulate the conduction of the society. The aim is to consolidate the organic bases of the sustainable development with strategies from the environmental movement; d) the cultural rationality is the rational action that produces the identity of the various cultural backgrounds, establishing social and productive practices for the environmental rationality (LEFF, 2002; 2004; 2006; 2008). These Weberian concepts do not have a strict meaning and share certain characteristics.

Foucault's concept of "environmental knowledge" considers the environmental issue as a sociological problem. This concept admits the presence of the identities of traditional peoples, their mysticism and traditional cultures as part of the natural resources and, therefore, values the 
practices of urban, rural and indigenous communities, incorporating the use of clean and innovative technologies and of self-management resources (LEFF, 2002; 2004).

Marx's socioeconomic theory allows the discussion of an academic, economic and social formation and of the means of production, having as a premise the study of society's structural processes. This conception provides a socio-economic and environmental formation through the articulation of technological, cultural and ecological processes with the economic market and public agencies (LEFF, 2002; 2004).

From these debates about the environmental aspects discussed by Diegues (1998; 2000), Leff (2002; 2004; 2006; 2008), Martínez-Alier (2007) and Viola (1987a; 1987b; 1992), it is evident that a study typology becomes necessary in order to identify the environmental conceptions in environmental organizations. In table 2 , a summary of the ideas discussed in this article is presented.

Table 2 - Typology of Environmental Conceptions.

\begin{tabular}{|c|c|}
\hline Environmental Conceptions & Characteristics \\
\hline $\begin{array}{l}\text { Preservacionist and "cult of wilder- } \\
\text { ness" }\end{array}$ & $\begin{array}{l}\text { Defense of nature in the prejudice of the human being and su- } \\
\text { pport of Biocentrism. Compliance with the environmental legisla- } \\
\text { tion. Economic security. }\end{array}$ \\
\hline Conservacionist & Harmonious relationship Nature - Market - Society. \\
\hline Sustainabilist & $\begin{array}{l}\text { Use of technology to overcome the environmental crisis. Environ- } \\
\text { mental services. Notions of cooperativism. }\end{array}$ \\
\hline Socio-environmentalist & $\begin{array}{l}\text { Participation of local communities and of social movements. So- } \\
\text { cial diversity. Fair distribution of income. Democratic participa- } \\
\text { tion in the management of territories. }\end{array}$ \\
\hline $\begin{array}{l}\text { Ecologism of the poor and/or envi- } \\
\text { ronmental justice }\end{array}$ & $\begin{array}{l}\text { Moderate legislation. Environmental Communitarian rights. Pro- } \\
\text { position of the discussion and of the creation of public policies so } \\
\text { that all the groups can have access to the environmental goods. }\end{array}$ \\
\hline $\begin{array}{l}\text { Ideological commitments of the en- } \\
\text { vironmental conceptions }\end{array}$ & Characteristics \\
\hline Eco-fundamentalist & $\begin{array}{l}\text { Of an anarchist and pessimistic inheritance. } \\
\text { Belief in the construction of an alternative society distant from } \\
\text { the consumerism. }\end{array}$ \\
\hline Eco-realistic & $\begin{array}{l}\text { Transformation of society through a rigid ecological movement regar- } \\
\text { ding its principles and flexible regarding its relationship with society. } \\
\text { A socio-economic system different from capitalism and socialism. }\end{array}$ \\
\hline Eco-socialist & Defense of a rupture with the capitalist society. \\
\hline Eco-capitalist & $\begin{array}{l}\text { Defense of the market as an allocator of resources. State of the } \\
\text { socio-ecological welfare. Ecological optimism. }\end{array}$ \\
\hline $\begin{array}{l}\text { Theories that sustain the environ- } \\
\text { mental conceptions }\end{array}$ & Characteristics \\
\hline $\begin{array}{l}\text { Environmental rationality } \\
\text { (Weber) }\end{array}$ & $\begin{array}{l}\text { Analysis of the challenges, of the practices and of the democra- } \\
\text { tic participation of the environmental movement; investigation } \\
\text { of the environmental discourse and its impact on social groups; } \\
\text { explanation of the strategies of power of the environmental mo- } \\
\text { vement; discussion of the degree of incorporation of the environ- } \\
\text { mental principles on the cultural rights in a multi-ethnical pers- } \\
\text { pective. }\end{array}$ \\
\hline $\begin{array}{l}\text { Concept of "Knowledge" } \\
\text { (Foucault) }\end{array}$ & $\begin{array}{l}\text { Analysis of the environmental discourse related to the principles } \\
\text { of cultural diversity, sustainability and social equity. Ideological } \\
\text { and cultural formations. }\end{array}$ \\
\hline Socio-economic analysis (Marx) & $\begin{array}{l}\text { Understanding of the structural processes of society. Understan- } \\
\text { ding of the socio-economic and environmental formation through } \\
\text { the articulation of the technological, cultural and ecological pro- } \\
\text { cesses with the economic market and the state. }\end{array}$ \\
\hline
\end{tabular}

Source: Adapted from Diegues (1998; 2000), Martínez-Alier (2007), Viola (1987; 1992) and Leff (2002; 2004; 2006; 2008). 


\section{METHODOLOGICAL PROCEDURES}

The three environmental organizations selected for this research develop actions related to the sustainable development and to the pursuit of sustainability. Located in different states and regions of Brazil, they also differ regarding their performances and target public. IOV works in family farms in the northern region of Mato Grosso, aiming at a social participation for the sustainable development. The work of FASE-MT consists in contributing for the creation of alternatives to the current model of development through the dissemination of agroecology, of the associativism and through the articulation among political agents and the communication in community radio and audiovisual projects. KANINDÉ acts in defense of the environment and works with indigenous and riverine peoples for the development of management plans in extractive reserves and protected areas in the state of Rondônia, in the northwest of Mato Grosso and in the southern Amazon.

This research presents characteristics of the study of multiple cases, one of the variations of the method, but does not differentiate itself from the single case study, most common in qualitative research (CRESWELL, 2010; YIN, 2010). The data collection research protocol presented in table 3 was adopted.

Table 3 - Research protocol for data collection.

\begin{tabular}{|c|c|}
\hline STAGE & ACTION \\
\hline $\begin{array}{l}\text { Review and reading of articles and books on EOs and } \\
\text { environmental conceptions. }\end{array}$ & $\begin{array}{l}\text { Mapping of the discussions on EOs and cataloging } \\
\text { the main environmental conceptions. }\end{array}$ \\
\hline Definition of the case units. & Research and mapping of EOs to be studied. \\
\hline $\begin{array}{l}\text { Concession of a formal authorization of the organiza- } \\
\text { tions to carry out field research. }\end{array}$ & $\begin{array}{l}\text { Identification of the coordinators responsible for } \\
\text { the EOs researched and, later, contact by e-mail } \\
\text { and telephone to present the research proposal. }\end{array}$ \\
\hline Preparation of the sampling plan. & $\begin{array}{l}\text { Identification and selection of the sample of the } \\
\text { EO members to be interviewed. }\end{array}$ \\
\hline Definition of the data collection instr & $\begin{array}{l}\text { Interview with the EO coordinators; observations } \\
\text { of the activities carried out and analysis of the the } \\
\text { formal documents from the organizations. }\end{array}$ \\
\hline $\begin{array}{l}\text { Research on the techniques of data analysis adequa- } \\
\text { te to the organizations investigated. }\end{array}$ & Use of audio and video, as well as written notes. \\
\hline Definition of the interview script. & $\begin{array}{l}\text { Creation of structural topics based on the problem } \\
\text { and research objectives. }\end{array}$ \\
\hline $\begin{array}{l}\text { Database to store the answers obtained from the } \\
\text { participants. }\end{array}$ & $\begin{array}{l}\text { Establishing codes for the EOs and environmental } \\
\text { conceptions to facilitate understanding and inter- } \\
\text { pretation of participants' answers. }\end{array}$ \\
\hline
\end{tabular}

Source: Elaborated by the authors based on Yin (2010; 2004).

In IOV, the activities of data collection took place during the month of February, in 2014, in the cities of Alta Floresta - Mato Grosso (MT), Terra Nova do Norte-MT and Carlinda-MT; in FASE-MT, it was in May 2014, in the cities of Cáceres-MT and Araputanga-MT; and, in the months of June and July 2014, in KANINDÉ in Porto Velho - Rondônia (RO) and Costa Marques (RO). The choice for these organizations was intentional, given to the fact that they belong to the Amazonian territory. These organizations also have a consolidated profile in the environmental discussions and already collaborated with the conduction of academic researches. The following procedures for data collection were carried out:

I Interviews: the focused and semistructured interview technique were used, as recommends Flick (2009): the interviewees were sensitized through an initial explanation by the researchers on the subject of the interview. For each organization, the sample of the interviewees was intentional, since two of the coordinators in charge of the management of each of the or-

Rev. AdM. UFSM, SANTA MARIA, v. 13, NúMERo 1, P. 20-39, 2020 
ganizations were selected, totaling six interviewees. The managers interviewed were registered through codes created to facilitate the writing and cataloging of the data. The codes were as follows: EK1 and EK2 for Kanindé; EF1 and EF2 for the MT-FASE; and EI1 and EI2 for the IOV. Each interview took an average of one hour to complete.

II Documental analysis: the coordinators of the organizations we were asked documents, such as statutes, minutes of general meetings, annual management reports and publications of projects already finalized or in progress. These documents were later read and analysed by the researchers, so that they could obtain the information regarding the characteristics of the environmental conceptions and, thus, analyze the similarities and differences in relation to the information collected during the interviews.

III Participant observation: researchers, concurrently with the interviews and the document analysis, observed the operation of these organizations in order to contact and interact with their various participants. The objective was to seek other subsidies to identify the environmental conceptions and clarify the way of execution of the organizations investigated.

For this research, a typology of environmental conceptions was proposed. To summarize this categorization, table 3 presents the elements that were the base for this study.

Table 3 - Identification of environmental conceptions, environmental commitments and theories.

\begin{tabular}{|c|c|}
\hline \multicolumn{2}{|r|}{ Environmental conceptions } \\
\hline Types & Indicators \\
\hline $\begin{array}{l}\text { Preservacionist and } \\
\text { "cult of wilderness" }\end{array}$ & $\begin{array}{l}\text { Fight for the preservation of nature; rigid legislation, opposed to economic grow- } \\
\text { th. }\end{array}$ \\
\hline Conservacionist & Defense of the integration among nature, market and society. \\
\hline Sustainabilist & $\begin{array}{l}\text { Defense of the use of technologies for forest management and advances in the } \\
\text { defense of a sustainable development. }\end{array}$ \\
\hline $\begin{array}{l}\text { Socio-environmen- } \\
\text { talist }\end{array}$ & $\begin{array}{l}\text { Approach to social and environmental movements. Discussion of projects aimed } \\
\text { at an equitable division of resources. Shared management of projects. }\end{array}$ \\
\hline $\begin{array}{l}\text { Ecologism of the poor } \\
\text { and/or environmental } \\
\text { justice }\end{array}$ & $\begin{array}{l}\text { Creation of green areas for traditional communities. Claim for legislative amend- } \\
\text { ments for injustices, especially those regarding the environmental rights of } \\
\text { communities. Integration of the traditional peoples in public policies for the ac- } \\
\text { cess to natural resources. Defense, for all social groups, of policies aimed at pro- } \\
\text { moting a social, economic and cultural empowerment. }\end{array}$ \\
\hline \multicolumn{2}{|r|}{ Ideological commitments } \\
\hline Types & Indicators \\
\hline Eco-fundamentalist & Avoids to take part in meetings with government agencies, entrepreneurs and society. \\
\hline Eco-realistic & Interaction with society through projects; belief in a pure environmentalism. \\
\hline Eco-socialist & $\begin{array}{l}\text { Contrary view to the capitalist system. Practices of participatory management; } \\
\text { participation in various projects with communities. }\end{array}$ \\
\hline Eco-capitalist & $\begin{array}{l}\text { Environment is not at risk of depletion. The economic system does not harm the } \\
\text { environment. Interaction with state agencies. }\end{array}$ \\
\hline \multicolumn{2}{|r|}{ Theories that sustain the environmental conceptions } \\
\hline Types & Indicators \\
\hline $\begin{array}{l}\text { Environmental ratio- } \\
\text { nality (Weber) }\end{array}$ & $\begin{array}{l}\text { Various biological and cultural resources; primacy of the moderate use of natural } \\
\text { resources. Distribution of income and power among the participants. }\end{array}$ \\
\hline $\begin{array}{l}\text { Concept of "Knowle- } \\
\text { dge" (Foucault) }\end{array}$ & $\begin{array}{l}\text { Lenders take part in the management of the organization. The target public takes } \\
\text { part in the activities. Use of natural products in the activities of the organization. }\end{array}$ \\
\hline $\begin{array}{l}\text { Socio-economic } \\
\text { analysis (Marx) }\end{array}$ & $\begin{array}{l}\text { Importance of the culture and the religion of the peoples. Understanding of the } \\
\text { environmental concepts. Structure of the decision-making process of the organi- } \\
\text { zation. Use of technologies that reduce the harm to the environmental. Participa- } \\
\text { tory management of the resources. }\end{array}$ \\
\hline
\end{tabular}

Source: Adapted from the literature. 
After that, there was a research protocol recommended for the case study (table 3) and it was also organized a database to carry out the analysis. In the end, the triangulation of the data collected and analysed in the interviews, the observations and the analysis of documents was carried out, in accordance with Creswell (2010) and Flick (2009).

Each characteristic observed was described in a worksheet with the spreadsheet editor of Microsoft Excel. After that, the information was compiled and analysed in order to identify the environmental conceptions. From this, a report with the results and discussions was generated. In order to decide on the prevalence of a certain environmental conception, ideological commitment or theory, in each organization, the adopted criterion was the presence of indicators in at least two of the three strategies of this research. For all the organizations, the criterion was the identification of the presence in at least two organizations.

\section{RESULTS AND DISCUSSIONS}

In this section of the article, results of research about the environmental conceptions that guide the organizations will be presented and discussed in order to, at last, identify some similarities and differences among the organizations based on their characteristics and views. Figure 1 shows the findings regarding the conceptions, the ideological commitments and the theories that were found in the organizations through research strategies.

It was identified that the three conceptions that are most present in the organizations are the socio-environmentalist, the sustainabilist and the environmental justice. In KANINDÉ, there is a strong presence of the conceptions conservationist, preservationist and "cult of wilderness". The eco-socialist ideological commitment is noticed in the three organizations. The eco-realism is identified in KANINDÉ and IOV. In FASE-MT, Marx's socio-economic theory and Foucault's "environmental knowledge" have been identified, whereas in IOV Marx's socio-economic theory and Weber's environmental rationality are present.

During the interviews, several conceptions were identified in the three organizations. This diversity is probably a result of the nature of the research strategy, which enables the access to the individual positions of the interviewees. So, it was possible to identify many points of view of the coordinators, in addition to those found in the documents and in the participant observation. This is due to the fact that the coordinators must have points of views originated from past professional experiences. 
Figure 1 - Summary of the environmental conceptions, ideological commitments and theories that were most fromenont in tho oroanizatione

Captions:

Preservationism-PR

"Cult of wildemess" - CW

Socio-environmentalist-SE

Environmentaljustice-EJ

Sustainabilism-ST

Conservationism - $\mathrm{CO}$

Eco-socialism - ES

Eco-realism - ER

Environmental rationality - ER

"Environmental

knowledge" - EK

Socio-economic-SEC

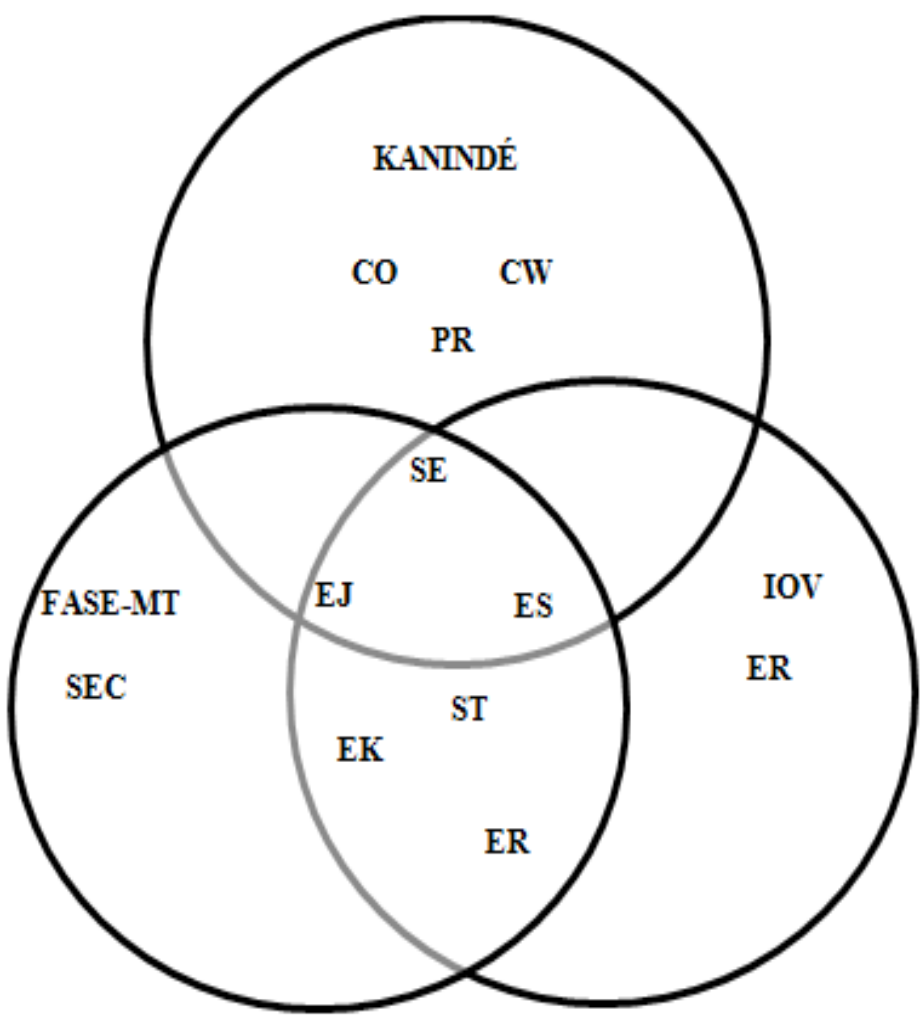

Source: By the authors.

In the documents obtained from the organizations, there are indicators of different environmental conceptions. It was inferred, therefore, that there is a fragmentation regarding the guidance of the organizations. However, in all documents, it was possible to find evidence, mainly, of the presence, the socio-environmentalist and of the environmental justice conceptions and of the eco-socialist commitment, the latter being identified in the documents from KANINDÉ and IOV. In IOV, documents show the presence of the eco-realistic and of the sustainabilist conceptions and of Foucault's "environmental knowledge".

The conceptions identified in the documents were also observed in the practices of the three organizations. According to the information collected in these documents and during the participant observation, the organizations develop their activities in accordance with what is proposed in the projects.

KANINDÉ is engaged in the pursuit of environmental rights, in the consolidation of public policies and in the sustainable use of technologies. The most frequent environmental conceptions identified in the documents of this organization were the environmental justice, the socio-environmentalism, the conservationism, the preservationism and the "cult of wilderness". Most of the documents analysed were ethno-zoning diagnostic reports and sustainable management plans that present conservationist features and are clearly influenced by partners such as government agencies, indigenous state agencies and financers. However, the analysis of the organization's institutional documents, such as its statute, revealed the presence of the socio-environmentalist and of the environmental justice conceptions and of the eco-socialist ideological commitment. In the management of the organization, the most present conceptions are the conservationist, the socio-environmentalist and the environmental justice, as well as the eco-socialist commitment. 
Preservationism and the "cult of the wilderness" are present in the KANINDÉ's Statute (p. 3), which, in its article 3, item XV, lists among its objectives the following: "to carry out and encourage environmental impact studies resulting from illegal actions in areas of permanent preservation". The interviewee EK2, when asked about the preference of the organization (human beings or nature), answered that "there is not [such a thing]. Man and nature are the same, there is no preference, it does not divided". According to the interviewee, the human being is also part of nature. This response demonstrates the organization's concern about nature and the view that the human being should not degrade the environment because it would harm mankind itself. The characteristics of the struggle for nature are expressed here through the concern with compliance with the environmental legislation.

The conservationist characteristics are present in the document "Participatory Ethno-environmental Diagnosis Methodology" (2010, p. 64): "[...] public use area corresponds to the specific places for the access of visitors seeking conservationist and ecotourism activities". During the observation participant process carried out in the Activity Plan of the Rio Cautário Extractive Reserve, in the municipality of Costa Marques, Rondônia, one of the collaborators stated that "[...] conservationism is a dream, that is what Kanindé is looking for". This indicates the existence of the conservationist conception in the vision of the members of the organization. These records are in tune with the conservationist view regarding the need to explore natural resources responsibly for the maintenance of nature (MCCORMICK, 1992; DIEGUES, 2000).

Kanindé's socioeconomic concern is present in the EK2's response when he said: "We believe that it is possible to work with ecology and, at the same time generate income, to have a sustainable development, we learned this from the indigenous peoples". In all the projects and actions in the communities and ethnic groups, it was noted a concern with the environmental, social and economic equilibrium and also with the practices for a sustainable development.

The statements of EK1 and EK2 are convergent. Both said that, of course, the organization seeks to combat and reduce environmental injustices. In this sense, there is concern about environmental injustices, especially in relation to indigenous peoples. Respondents also showed respect for the culture and religiosity of indigenous people, farmers and river dwellers.

The conceptions and ideological commitments identified in KANINDÉ are discussed by Martínez-Alier (2007) and Viola (1987a; 1987b; 1992). The presence of the various environmental conceptions can be justified by a preoccupation with the distribution of income, with the environmental rights of indigenous peoples and with a shared management of the projects. In KANINDÉ, the influence of Diegues' (1998) conservationist and preservationist conceptions and Martínez-Alier's (2007) "cult of wilderness" should be emphasized. This is due to the experience of the coordinators, to the characteristics of the projects and to the target public of the organization. These results are partially in accordance with the conceptions that were hypothesized in the beginning of this work, except regarding the environmental justice, which was not identified.

FASE-MT seeks to improve the quality of life of rural communities and of quilombolas. In the organization's documents, fragments indicated the presence of the socio-environmentalist, sustainabilist and environmental justice conceptions, as well as of the eco-socialist ideological commitment. In the interviews, the eco-realistic presence has been identified, but there was no evidence of the influence of this ideological commitment in the activities of the organization. The theories of the "environmental knowledge" and of Leff's (2002; 2004; 2006; 2008) socioeconomic analysis were found in the interviews and in the participant observation.

The environmental conceptions identified as having a greater presence in the activities of FASE-MT were the socio-environmentalist, environmentalism of the poor (or environmental justice) and the sustainabilist. The socio-environmentalism is used strategically, since the organization was 
founded based on this conception, which is present in every planning and in every action of the organization's projects. The socio-environmentalism and environmental justice conceptions are supported by the socio-economic theory and by the concept of the "environmental knowledge", since the organization applies a participative design in the decision making with a marked environmental discourse and denoting an eco-socialist ideological commitment contrary to the capitalist system.

FASE-MT's mission statement is presented in a presentation document released by the institution: "FASE's mission is to contribute to the construction of a democratic society through a developmental alternative that contemplates social inclusion and justice, sustainability of the environment and the universalization of social, economic, cultural, environmental, civil and political rights". This text presents features of the environmental justice conception discussed by Martínez-Alier (2007) and Acselrad (2010) and socio-environmentalist aspects discussed by Diegues $(1998,2000)$, as it captures the organization's concern with less favored communities, as well as the search for environmental rights. The mission of the organization points to the search for social inclusion through actions that can contribute to a better society.

The sustainabilist conception is identified due to the characteristics of the actions directed at FASE-MT's target public and to the use of agroecology in the organization's most important outreach projects in Mato Grosso. This can be identified in EF2's discourse. When questioned about the use of technologies to help defend sustainable development, he said: "[...] In agroecology, various technologies are developed from the understanding of the reality of the territory or community [...]. And this vision has contributed to the defense of sustainable development". In the management of the organization, the most present conceptions were the socio-environmentalist, the environmental justice and the sustainabilist. The ideological commitment was the eco-socialist, and the theories were the socioeconomic analysis and the "environmental knowledge".

According to the findings of this work, the conceptions that were hypothesized in the beginning of the article were partially found in the organizations. Only the socio-environmentalist conception and eco-socialist ideological commitment were identified in the organization. However, there is also a marked presence of the environmental justice, which was not mentioned as a possible conception of FASE-MT.

In IOV, the environmental conceptions that stood out in the documents that were analysed were the socio-environmentalist, the environmental justice, the sustainabilist and the conservationist, the latter having a not so much prominent influence in the activities of the organization. The theory of the "environmental knowledge" and the eco-realistic and eco-socialist ideological commitments were also found in the documents. In the interviews with the coordinators of the organization, besides what was found in the documents, it was also identified the presence of the environmental rationality theory discussed by Leff $(2002 ; 2004 ; 2006 ; 2008)$, which is related to Diegues's (1998) sustainabilist conception. The conceptions identified during the observations of the organization's activities were the socio-environmentalist, the environmental justice and the sustainabilist and the eco-realistic ideological commitment, as well as the socioeconomic theory and Weber's environmental rationality.

In IOV, the conceptions socio-environmentalist, ecologism of the poor and/or environmental justice are supported by eco-realistic and eco-socialist ideological commitments and the by Marx's socio-economic theory. This is justified by the following aspects found during the research: the organization's concern with the improvement of income and the empowerment of family farms; the insertion of certain communities in society and in public policies; encouragement given to the participation and to the interaction of social movements with society and the practice of self-management and of cooperativism. The environmental rationality supports the 
sustainabilist presence through a political plurality, being identified in the organization by the use of agroecological techniques and of sustainable technology. Observing the actions of IOV, the hypotheses of this study were supported by the presence of the conceptions sustainabilist and socio-environmentalist and of the eco-socialist ideological commitment. However, the presence of the environmental justice and of the eco-realistic conceptions were also found, although they are not strategically used by the organization.

The socio-environmental indicators and environmentalism of the poor and/or environmental justice are present in all the documents analyzed. The presence of these conceptions in the actions of IOV are important because they influence all of their activities. The "Territorial Plan for Sustainable Rural Development" (PTDRS) describes:

Land tenure actions are basically related to land regularization and agrarian reform. These actions are considered essential in the search for a new model of development in agriculture, making the land a peaceful area, an area of production and social justice. The distribution and regularization of land, but that, together with these actions, public policies, infrastructure and production, especially able to guide the settlers of agrarian reform, are made available. $(2010,31)$.

Foucault's "environmental knowledge" is present in IOV, as verified in the document "Planejamento do Instituto Ouro Verde 2013-2014" (p. 11, s.d.).

\begin{abstract}
The dissemination of proposals that are said to be 'sustainable' means that institutions need to be clear about their position against [sic] the clash between the idea of improving the system or changing society. It is not a matter of saying which is the position that can be considered correct, but rather of having coherence regarding the principles and the actions performed.
\end{abstract}

Observing the actions of IOV, the hypotheses of this study were supported by the presence of the conceptions sustainabilist and socio-environmentalist and of the eco-socialist ideological commitment. However, the presence of the environmental justice and of the eco-realistic conceptions were also found, although they are not strategically used by the organization.

During the analysis of the environmental conceptions in the environmental organizations, similarities and differences were noted. The methodology adopted allowed an understanding of the characteristics and of the indicators of the environmental conceptions present in the organizations.

Regarding the similarities, it is possible to argue that the conceptions preservationist and "cult of wilderness" and the eco-fundamentalist ideological commitment share many similarities. The most important one is the defense of an untouched nature, as discussed by Diegues (1998). These conceptions were only identified in KANINDÉ, once it is the only organization, among the three surveyed, that develops its activities with indigenous peoples, that need part of their territory to be preserved in order for them to guarantee the perpetuation of their culture. Nevertheless, it is not possible to state that these conceptions may influence the performance and the management of that organization. In two organizations, FASE-MT and IOV, relevant indicators of the adoption of these conceptions were not found.

Foucault's concept of "environmental knowledge" and the ideological commitment eco-realistic are associated with the sustainabilist conception regarding the use of the innovation and of clean technologies and of the self-management approach. These aspects are present in the activities of the three organizations studied, which enables the conclusion that this theory and this ideological commitment support the sustainabilist conception.

Regarding the differences, the divergences between the preservationist and the conser- 
vationist conceptions are evident: the first is based on the ideal of an untouched nature (biocentric); the second allows the handling of nature for economic and social purposes (anthropocentric vision). KANINDÉ has as one of its strengths actions that advocate the use of the environment with responsibility, allowing human interaction with the natural resources, a conservationist feature, as described by Gómez-Pompa and Kaus (2000).

In IOV, the presence of the socio-environmentalist and of the sustainabilist conceptions was identified. The difference between these conceptions relies in the fact that the approach to public policies is markedly socio-environmentalist and the presence of the interaction with technology in support of the economic growth is one of the sustainabilist features. Regarding the interaction with the target audience and the opinion towards the economic system, it was identified, with a greater presence, the eco-socialist commitment. Its supporters are against the capitalist system, a fact that is notorious in the actions of the three organizations. The eco-realistics support the interaction with society through projects, which is found in IOV.

Therefore, in FASE-MT, there is the presence of Marx's socio-economic theory, of the eco-socialist commitment and of sustainabilist conception. The presence of the first and of the second was identified based on the discourse and practices of the employees of the organization. From the three organizations surveyed, FASE-MT was the one in which the Marxist theories were found to be more expressive; regarding the sustainabilist conception, the defense of agroecology can be highlighted. This type of technology is used in the organization's projects aimed at local communities. Therefore, the environmental organizations analysed have directly or indirectly characteristics and indicators that reflect the presence of various environmental conceptions in their performances.

\section{CONCLUSIONS}

In the literature, it is possible to identify various environmental conceptions, some with similar characteristics and indicators, which indicates a difficulty in identifying a single conception in the analysis of the environmental organizations. Studying the conceptions in these organizations helps to understand the way of management of their activities and of their projects and can, therefore, help align their discourse with their practices by relating them to their agents and supporters.

In KANINDÉ, the conception with a greater frequency of indicators is the socio-environmentalist. The conservationist presence is justified by the characteristics and by the influence of entities and ethnic groups that demand the work of the organization. The preservationist and the "cult of wilderness" conceptions are present, possibly due to the fact that the organization deals with indigenous peoples who need preserved areas for the continuation of their ethnic groups and cultures.

In FASE-MT, even with a marked presence of the characteristics of the environmental justice conception, the organization recognized itself only as socio-environmentalist, which allows the conclusion that this is due to the lack of a more consistent discourse of the members of the organization that defend these views. The absence of the conservationist conception was also noted as an influential aspect of FASE-MT's activities.

The environmental conceptions that influence the management and performance of IOV were the socio-environmentalist and the environmental justice. The organization seeks to promote actions that result in the strengthening of the income of family farms associated with the organization.

Overall, the conservationist conception was not identified as having a marked presence in the activities of FASE-MT and of IOV, as initially supposed. The environmental justice conception was found in the three organizations, although it was not likely to be identified, as well as the eco-realistic commitment. These environmental conceptions are not discussed strategically, especially in relation to the environmental justice. These environmental conceptions that are more 
present converge in many characteristics such as the dealing with social agents, the environmental and human rights and the concern with the sustainable development and with income distribution.

Environmental conceptions, ideological commitments and theories influence strategic plans, beliefs, values of management, environmental planning and the policy of environmental organizations. Therefore, organizations need to identify and use these environmental aspects to diagnose problems and seek solutions to better develop their activities, considering their stakeholders.

The presence in the organizations of indicators of the three theories previously mentioned was identified in their activities with different levels of emphasis. However, although they are present, an awareness of these theories by the organizations and their employees was not identified. Given these findings, it is suggested that the organizations discuss, strategically, the environmental justice conception so that they can apply it more effectively into their activities.

It is also suggested that further investigations be carried out and that they involve other social actors and other environmental organizations with activities in other regions of the country and with different target publics. Other environmental conceptions and authors that were not selected in this research ought to be studied, aimed at understanding the differences between the environmental conceptions and the ideological commitments that were found in the organizations and were not hypothesized in this work. It is also suggested the execution of researches with mixed and/or quantitative methods in the investigated or in other environmental organizations. Discussing the conceptual tensions that exist in the theories proposed by Marx, Weber and Foucault is also a suggestion for further studies, as well as carrying out researches with mixed and/or quantitative methods of the investigated organizations or other environmental organizations.

\section{REFERENCES}

BECKER, Bertha. K. Geopolítica da Amazônia. Estudos Avançados, Vol. 19, n. 53, 2005, p. 71-86. online: http://www.scielo.br/pdf/ea/v19n53/24081.pdf. Accessed 15 March. 2016.

BOEIRA, Sergio. Luís. Ambientalismo complexo-multissetorial no Brasil: emergência e declínio na década de 1990?. Revista Ibero-americana de Ciências Ambientais, Vol 7, n. 3. 2016. online: http://sustenere.co/journals/index.php/rica/article/view/1336. Accessed 16 December 2016.

BOFF, Leonardo. Ecologia: grito da terra, grito dos pobres. São Paulo, Ática, 2005.

BORN, Rubens Harry. Compensações por Serviços Ambientais: sustentabilidade ambiental com inclusão social. In: BORN, Rubens. Harry (Ed). Diálogos entre as esferas global e local: contribuições de organizações não-governamentais e movimentos sociais brasileiros para a sustentabilidade, equidade e democracia planetaria. , São Paulo Peiropolis, 2002. p. 49-66.

CASTELLS, Manuel. O poder da identidade. 3ed. São Paulo, Paz e Terra, 1999.

CRESWELL, John. Projeto de pesquisa: métodos qualitativo, quantitativo e misto. 3 ed. Porto Alegre, Booking/Artimed, 2010.

DIAS, Reinaldo. Gestão ambiental: responsabilidade social e sustentabilidade. São Paulo, Atlas, 2009.

DIEGUES, Antônio Carlos. Etnoconservação da natureza: enfoques alternativos. In: $(E d)$. Etnoconservação: novos rumos para a proteção da natureza e dos trópicos. São Paulo Hucitec, 2000, p. 1- 46. 
O mito moderno da natureza intocada. 2 ed. São Paulo, Hucitec, 1998.

DRUMMOND, José Augusto L. A visão conservacionista (1920 a 1970). In SVIRSKY, Enrique; CAPOBIANCO, João Paulo R. (Eds.). Ambientalismo no Brasil: passado, presente e futuro. São Paulo, Instituto Socioambiental - Secretaria do Meio Ambiente do Estado de São Paulo, 1997, p. 19-26.

FLICK, Uwe. Introdução à pesquisa qualitativa. Artmed, 3. ed., Porto Alegre, 2009.

GÓMEZ-POMPA, Arturo; KAUS, Andrea Domesticando o mito da natureza selvagem. In: Diegues, Antônio Carlos (Ed.) Etnoconservação: novos rumos para a proteção da natureza e dos trópicos. São Paulo, Hucitec, 2000, p. 124-148.

GOHN, Maria da Glória. Movimentos sociais na contemporaneidade'. Revista Brasileira de Educação, Vol. 16, n. 47, 2011, p. 333-363. online: http://www.scielo.br/pdf/rbedu/ v16n47/v16n47a05.pdf. Accessed em 26 November. 2013.

GOLDSMITH, Edouard. O desafio ecológico. Lisboa, Piaget, 1995.

JACOBI, Pedro. Movimento ambientalista no Brasil: representação social e complexidade da articulação de práticas coletivas. In: Ribeiro, W. (Ed.). EDUSP, 2003. online: http://www. cpd1.ufmt.br/gpea/pub/jacobi_movimento\%20ambientalista-brasil-edusp.pdf. Accessed 10 October 2013.

LEFF, Enrique. Epistemologia ambiental. 2. ed. São Paulo, Cortez, 2002. Aventuras da epistemologia ambiental: da articulação das ciências ao diálogo de saberes. Rio de Janeiro, Garamond, 2004.

- Racionalidade ambiental: a reaproapriação social da natureza. Rio de Janeiro, Civilização Brasileira, 2006.

Saber ambiental: sustentabilidade, racionalidade, complexidade e poder. 6 ed. Petropólis, Vozes, 2008.

LEIS, Hector Ricardo. A modernidade insustentável: as críticas do ambientalismo à sociedade contemporânea. Montevideu, Coscoroba ediciones, Centro Latino Americano de Ecologia Social, 2004.

LEROY, Jean Pierre. Meio ambiente de mercado ou meio ambiente de justiça? In CORRÊA, Aureanice de Mello et al. A floresta: educação, cultura e justiça ambiental. São Paulo, Garamond, 2013, p.176-186.

LOSEKANN, Cristiana. Ambientalismo em movimento no Brasil: entrelaçamentos e tensões entre o estado e a sociedade durante o governo Lula. Curitiba, Appris, 2014.

LOUREIRO, Maria. Rita; PACHECO, Regina Silvia. Formação e consolidação do campo ambiental no Brasil: consensos e disputas (1972-92). Revista de Administração Pública. Vol. 29, n. 4, Oct.-Dec. 1995. p. 137-153. online: http://bibliotecadigital.fgv.br/ojs/index.php/rap/ article/view/8267/7052. Accessed 15 March 2016.

LOWY, Michael. O que é ecossocialismo. 2. ed. São Paulo, Cortez, 2014. 
MARTÍNEZ-ALIER, Joan. Justiça Ambiental (local e global. In: CAVALCANTI, Clóvis. (Ed.). Meio ambiente, desenvolvimento sustentável e políticas públicas. 4. ed. Recife, Fundação Joaquim Nabuco, São Paulo; Cortez, 2002, p. 215-231.

. O ecologismo dos pobres: conflitos ambientais e linguagens de valoração. São Paulo, Contexto, 2007.

MEBRATU, Desta. Sustainability and sustainable development: historical and conceptual review. Elsevier, New York. Vol. 18, issue 6, 1998, p. 493-520. online: http://www.sciencedirect. com/science/article/pii/S0195925598000195. Accessed 03 October 2013.

MENEZES, Daniel Santos. 2008. Ambientalismo, conhecimento tradicional e reservas extrativistas na Amazônia legal: a visão dos técnicos do instituto Chico Mendes. 163f. Dissertação de Mestrado. Unir. Mestrado, Porto Velho. 2008. online: http://www.dominiopublico.gov.br/ pesquisa/DetalheObraForm.do?select_action=\&co_obra=112314. Accessed 30 August 2013.

; Siena, Osmar. Ambientalismo no Instituto Chico Mendes de Conservação da Biodiversidade (ICMBIO) na Amazônia Legal. O\&S. Salvador, Vol. 17, n. 54, Jul-Set, 2010, p. 479-498. online: http://www.spell.org.br/docu mentos/ve r/486/ambientalismo-no-instituto-chicomendes-de-cons---. Accessed 15 November 2013.

MONTIBELLER-FILHO, Gilberto. O mito do desenvolvimento sustentável: meio ambiente e custos sociais no moderno sistema produtor de mercadorias. Florianopólis, Editora da UFSC, 2008.

PÁDUA, José Augusto. Natureza e projeção nacional: nascimento do ambientalismo brasileiro (1820-1920). In: SVIRSKY, Enrique; CAPOBIANCO, João Paulo R (eds.). Ambientalismo no Brasil: passado, presente e futuro. São Paulo: Instituto Socioambiental: Secretaria do meio ambiente do Estado de São Paulo, 1997. p. 13-18.

PEPPER, David. Ambientalismo moderno. Lisboa, Piaget. 1996.

PIMBERT, Michael. P; PRETTY, Jules N. Parques, comunidades e profissionais: incluindo 'participação' no manejo de áreas protegidas. In: DIEGUES, Antônio Carlos. (Ed.). Etnoconservação: novos rumos para a proteção da natureza e dos trópicos, São Paulo, Hucitec, 2000, p. 183-223.

RUCKERT, Fabiano Quadros. O ambientalismo em três escalas. Cadernos IHU, São Leopoldo, ano 13, n. 51. 2015. online: http://www.ihu.unisinos.br/images/stories/cadernos/ ihu/051cadernosihu.pdf. Accessed 11 Setember 2016.

SANTILLI, Juliana Socioambientalismo e novos direitos: proteção jurídica à diversidade biológica e cultural. São Paulo, Peirópolis, 2005.

SCHWARTZMAN, Stephan. Floresta cercadas: lições do passado, propostas para o futuro. In DIEGUES, Antônio Carlos (Ed.). Etnoconservação: novos rumos para a proteção da natureza e dos trópicos. São Paulo, Hucitec, 2000, p. 257-272.

SILVA, José Kennedy L.; SIENA, Osmar. Perfil da produção científica sobre organizações ambientalistas. Revista de Gestão Ambiental e Sustentabilidade, v. 3, n. 3, p. 34-47, 2014. Disponível em: http://www.spell.org.br/documentos/ver/39188/perfil-da-producaocientifica-sobre-organizacoes-ambientalistas/i/pt-br. Acesso em: 25 set. 2016. 
. As influências dos compromissos ideológicos e das teorias de base para asconcepc,ões ambientais da Associação de Defesa Etnoambiental Kanindé. REGE - Revista de Gestão. Vol. 23, n. 4, Out-Dez 2016, p. 338-348. Disponível em: http://www.sciencedirect.com/ science/article/pii/S1809227616305999?via\%3Dihub. Acesso em: 24 jan. 2018.

VIOLA, Eduardo J. O movimento ecológico no Brasil (1974-1986): do ambientalismo à ecopolítica. In: PÁDUA, José Augusto. (Ed.). Ecologia e política no Brasil. Rio de Janeiro, Espaço e tempo, 1987a, p. 63-109.

. Heterogeneidade política. Lua Nova. Vol. 3, n. 4, 1987b, p. 45-49. online: http://www. scielo.br/pdf/In/v3n4/a06v3n4.pdf. Accessed 20 November. 2013.

. A dinâmica do ambientalismo e o processo de globalização. São Paulo em Perspectiva. São Paulo. 1992. online: http://www.seade.gov.br/produtos/spp/v06n01-02/v06n0102_02.pdf. Accessed 23 Setember 2013.

; VIEIRA, Paulo F. Da preservação da natureza e do controle da poluição ao desenvolvimento sustentável: um desafio ideológico e organizacional ao movimento ambientalista no Brasil. Revista de Administração Pública. Rio de Janeiro. Vol. 4, Out/Dez, 1992, p. 81-104. online: http://bibliotecadigital.fgv.br/ojs/index.php/rap/article/view/8724. Accessed 23 Setember 2013.

YIN, Robert. K. Estudo de caso: planejamento e métodos. 4 ed. São Paulo, Bookman, 2010.

ZHOURI, Andrea. O ativismo transnacional pela Amazônia: entre a ecologia política e o ambientalismo de resultados. In. Horizontes Antropológicos. Porto Alegre, ano 12, n. 25, jan-jun, 2006. p. 139-169. online: http://www.scielo.br/pdf/ha/v12n25/a08v1225.pdf. Accessed 19 November 2013.

Contribution of authors

\begin{tabular}{|l|c|c|}
\hline \multicolumn{1}{|c|}{ Contribution } & [Author 1] & [Author 2] \\
\hline 1. Definition of research problem & $\mathrm{V}$ & $\mathrm{V}$ \\
\hline 2. Development of hypotheses or research questions (empirical studies) & $\mathrm{V}$ & $\mathrm{V}$ \\
\hline $\begin{array}{l}\text { 3. Development of theoretical propositions } \\
\text { (theoretical work) }\end{array}$ & $\mathrm{V}$ & $\mathrm{V}$ \\
\hline 4. Theoretical foundation / Literature review & $\mathrm{V}$ & $\mathrm{V}$ \\
\hline 5. Definition of methodological procedures & $\mathrm{V}$ & $\mathrm{V}$ \\
\hline 6. Data collection & $\mathrm{V}$ & \\
\hline 7. Statistical analysis & & \\
\hline 8. Analysis and interpretation of data & $\mathrm{V}$ & \\
\hline 9. Critical revision of the manuscript & & $\mathrm{V}$ \\
\hline 10. Manuscript writing & $\mathrm{V}$ & \\
\hline 11. Other (please specify) & & \\
\hline
\end{tabular}

